\title{
The Lynching and Rebirth of Ned Buntline: Rogue Authorship during the American Literary Renaissance
}

\section{ABSTRACT}

Though largely unknown today, "Ned Buntline" (Edward Zane Carroll Judson) was one of the most influential authors of $19^{\text {th }}$-century America. He published over 170 novels, edited multiple popular and political publications, and helped pioneer the seafaring adventure, city mystery and Western genres. It was his pirate tales that Tom Sawyer constantly reenacted, his "Bowery B'hoys" that came to define the distinctive slang and swagger of urban American characters, and his novels and plays that turned an unknown scout into Buffalo Bill, King of the Border Men. But before "Ned Buntline" became a mainstay of the popular press, he had been on his way to becoming one of the nation's highbrow literary elites. He was praised by the leading critics, edited an important literary journal, and his stories appeared in the era's most prestigious publications. This study examines how and why "Ned Buntline" moved from prestigious to popular authorship and argues that the transformation was precipitated by one very specific event: in 1846, Edward Z. C. Judson was lynched. A close examination of Judson's life, writing, and the coverage of him in the newspapers of the day (including the remarkable story of how he survived a lynching) demonstrates that the same issues that led to his lynching also led to his rebirth as a new kind of American author.

Keywords: Ned Buntline, antebellum American fiction, $19^{\text {th }}$-century popular press, publishing history, lynching. 
A few minutes after ten o'clock on Saturday night, 14 March 1846, a band of angry men broke into the Nashville Tennessee Court House, overpowered the jailor, and dragged Edward Z. C. Judson from his prison cell out into the Public Square. A rope was coiled about his neck and a mob of citizens looked on as his already broken body was hauled up an owning post, his legs kicking as he dangled in the night air. Amazingly, this event did not end Judson's life, but it did change it forever. During the two years before this life-altering event, Judson's star had been rising. He had launched a well-respected journal that promoted the literary efforts of America's expanding West, gained the support of the nation's most prominent editors and writers, and wrote entertaining tales that regularly appeared in the elite literary publications of the day. Judson was on his way to being a significant author of the American Literary Renaissance. But when the rope was cut and he fell to the ground, gasping and choking for breath, he was reborn as a different kind of writer. The events that led to his lynching taught him some important lessons that changed the way he thought about writing. From this point forward, Judson fully embraced his emerging literary alter-ego, "Ned Buntline," and abandoned the highbrow literary world to become one of the leading figures of the popular press. Over the next forty years his scandalous city-mysteries shocked and entertained America's increasingly urban population, his novels and plays turned an unknown Western scout into Buffalo Bill, King of the Border Men, and his nautical yarns inspired Mark Twain's Tom Sawyer to join thousands of other youth across the nation, acting out the sensational pirate tales they read about in Buntline's stories. His writing also drove filibustering efforts in Cuba, temperance crusades in California, and helped launch the Know-Nothing party that rattled American politics in the mid-1850s. Ned Buntline, though largely forgotten today, was a house-hold name in the mid-19 $19^{\text {th }}$ century and arguably one of its most influential authors. ${ }^{1}$

This study focuses on the months immediately surrounding Judson's lynching to explain why an up-and-coming author would switch from the elite world of belles-lettres to the cheap, sensational publishing market

1 Judson published at least 170 novels as "Ned Buntline" between 1846 and his death in 1886. His 1848 Mysteries and Miseries of New York was among the most popular of the era's "city mystery" novels; his publication of Buffalo Bill, King of the Border Men (1869) and play "The Scouts of the Prairie" (1872) launched William Cody's fame and America's obsession with the Western; and in chapter 13 of Mark Twain's The Adventures of Tom Sawyer, Tom proclaims himself, "Tom Sawyer, the Black Avenger of the Spanish Main!" and his friends chime in that they are "Huck Finn the Red-Handed, and Joe Harper the Terror of the Seas," all characters from pirate tales by Ned Buntline from the 1840 s. 
that was just beginning to emerge in 1840s America. It also serves as a case-study for the argument outlined in Jane Tompkins's seminal work, Sensational Designs: The Cultural Work of American Fiction, 1790-1860 that redefined the study of American literature, moving it "away from a small group of master texts" and toward a more egalitarian "redefinition of literature" that saw novels not as "works of art embodying enduring themes in complex forms" but as cultural creations that attempted "to redefine the social order" (xi). She saw books not as artworks designed to "be enshrined in any literary hall of fame," but as didactic and dynamic texts designed "to win the belief and influence the behavior of the widest possible audience" and "to make people think and act in a particular way" (xi). Her goal was not simply to create a wider pool of authors available for academic study, but to look specifically for texts that did significant "cultural work" and that had "traction in their original setting" (xv). She argued that a "text succeeds or fails on the basis of its 'fit' with the features of its immediate context, on the degree to which it provokes the desired response" (xviii). What Tompkins described is what Judson realized as he hung from an awning post in Nashville. He had dabbled in a new writing style that proved capable of provoking a powerful response. It was not yet the response he desired - that was the part he needed to figure out. During his long months of recovery, this realization caused a metamorphosis. $\mathrm{He}$ abandoned his place among the elite writers of his day and embraced the life of a writing rogue with an authorial voice that would cause riots, launch political parties, and make him one of the most innovative and important writers of his era.

\section{$\ddot{*}$}

Edward Zane Carroll Judson, known throughout his life as "Ned,"2 was born in the small village of Stamford deep in New York's Catskill Mountains on 20 March 1823. His father, Levi Carroll Judson was a school teacher and principal who moved the family first to rural Pennsylvania and then, when Ned was eleven, to Philadelphia where Levi became an attorney and cultivated his authorial ambitions, writing a book on the Founding Fathers of America. Levi pressed his teen-aged son to read law and join him as an attorney, but Ned, still longing for the adventure and freedom of his rustic childhood, ran off to sea, sailing first aboard merchant vessels

2 This article discusses both the man, Edward "Ned" Zane Carroll Judson, and his literary persona, "Ned Buntline." Instead of alternating between "Judson" and "Buntline" it will address him as "Ned" throughout the text to avoid confusion. 
in the Caribbean and then as a Midshipman in the US navy starting in 1837. During his navy years he saw action in the Second Seminole War and acquired a bit of a literary reputation himself, having one of his rollicking tales printed anonymously by New York's prestigious Knickerbocker Magazine in 1838 (Buntline, "My Log-Book"). On 12 December 1841 he took a Spanish bride, Severina Tecla Marin, in St. Johns, Florida—six months later he left the navy and they moved to New York. Records don't show what the young couple did for the next two years, but by December of 1843 , Ned had gone to Pittsburgh to reestablish connections with his family who had moved there a few years earlier. He initially left Severina behind to give him some time to convince his Nativist father to accept his Spanish bride and her Catholic faith. ${ }^{3}$

By May of 1844 Ned was feeling more secure. He moved Severina to Pittsburgh and with his father launched Ned Buntline's Magazine featuring his new nautical nom de plume on its masthead. Though it failed after only two issues, it garnered the attention of prestigious editor, Lewis Gaylord Clark, who wrote in his Knickerbocker Magazine:

Ned Buntline... Your craft makes a right gallant appearance, and seems manned by a hearty crew, who have abundant ability, and do their work with a will. .. and if the 'OlD KNICK' can serve your interests at any time, let him know the how and the when. That you will deserve encouragement and substantial patronage, is quite certain" (Clark, "Editor's Table” Jul. 1844: 102).

With praise from such high places, Ned was able to gain a new partner, Lucius A. Hine, and in November of 1844 they launched the Western Literary Journal and Monthly Review in Cincinnati, Ohio, then the publishing capital of America's expanding West. Their journal was well received and by January of 1846 they picked up another partner, Hudson Kidd, who helped expand the publication into the South with a new office in Nashville, Tennessee. By early 1846 Ned moved Severina from Cincinnati to Nashville while he continued to shuttle between, working with both Hine and Kidd, and collecting subscriptions and stories at every steamboat wharf up and down the Ohio and Cumberland Rivers that connected the two cities (Larsen 111-12; Venable 304-05). On the literary front, things were going very well. Hine provided the funds to bankroll the new publication until it got on its feet, and the Knickerbocker had accepted two swashbuckling tales of the Caribbean from "Ned Buntline" for both

3 This quick overview of Buntline's early life comes from Bradshaw, Larsen, Monaghan, and Pond. Judson's birth year is disputed-a claim for 1821 can also be made. 
its October and December issues. Clark praised the Literary Journal and Ned especially, saying: "There is a certain life, a semblable spirit, in every thing we have seen from his pen, that renders him a most entertaining companion" (Clark, "Editor's Table” Dec. 1844: 582-83).

Having spent the past several months traveling along America's river ways trying to drum up support for the journal, Ned began to realize that what they were publishing was not what Americans actually wanted to read. America was a land of practical, frank people who enjoyed sentimental poetry, scandalous gossip, and exciting stories in which hardworking people triumphed over injustice. ${ }^{4}$ This was not what their journal was publishing. In fact, they were condemning such works. He himself had harshly reviewed popular authors for writing stories that were too sensational, too scandalous, and too hastily written. George Lippard, a blood-and-thunder writer from Philadelphia, had released The Ladye Annabel; or, the Doom of the Poisoner and Ned responded like all proper editors, finding it “only extraordinary for its quantity of 'incident,' strange, fearful and thrilling” (Buntline, Western Literary Journal Nov. 1844: 63). This, however, had not prevented them from reprinting three columns of an especially gruesome part of the story; that they accompanied it with a stern warning that such writing would bring "Mr. Lippard much injurious fame" (58-59), didn't obscure the obvious-this was engaging writing that people wanted to read. Ned had also ridiculed the popular author Joseph Holt (J. H.) Ingraham's new book The Midshipman, beginning his review: "Ingraham has written a great deal upon subjects of which comparatively he knows nothing" (26). As a former Midshipman himself, Ned gleefully noted dozens of factual mistakes while also mocking Ingraham for the rapidity at which he wrote. In a review in their next edition, he noted that Ingraham had already produced two new works, doing so by simply taking headlines from news stories and converting them into sensational ten-chapter novellas (Buntline, Western Literary Journal Dec. 1844: 112-13). Then, in a review of Lippard's The Quaker City, a hugely popular book that used thinly-veiled characters to expose the misdeeds of Philadelphia's prominent residents, Ned reluctantly admitted that he was "somewhat amused with the hits which are given to some persons ... one can scarce help laughing at the duplicate" (Buntline, Western Literary Journal Jan. 1845: 183). But ultimately he condemned the quick, overly-sensational writing: "We regret to see [Lippard], like Professor Ingraham, prostituting his able pen in recording, in a trifling

4 Further information on America's reading habits in the mid-1840s can be found in Streeby's American Sensations (81-101) and Denning's Mechanic Accents (27-41). 
novellette shape, scenes which have already cast a sufficient blot and stain upon our land" (183). He moralistically concluded: "Seek nobler themes, and loftier notes will be your reward" (183).

Ned also began to come to a financial realization-despite his growing literary prestige, he and Severina were barely making it. The Knickerbocker promised funds but was often slow to deliver and never offered enough work to make ends meet (Monaghan 299). And though the Literary Journal received much praise, it wasn't making money-Severina, despite her ill health, picked up factory piece-work just to pay the rent (Larsen 112). In light of this, Ned began to lose interest in the Literary Journal and to believe that Lippard and Ingraham were right. It was their works that people were buying and reading. Why not engage in the same game, only do it better? After all, he was doing well among the elite publications of the country not because he was writing on more sophisticated or enlightened themes, but because he was writing exactly the same sort of sensational stories, but writing them better. His tales were sophisticated enough to impress the elite "Knickerbocker Group," but amusing enough to also appeal to the masses. Why not capitalize on this? Thanks to the Knickerbocker "Ned Buntline" was well-known-a name that denoted rollicking, well-written stories. He could use this fame to launch a publication of his own, one that wouldn't come out at regular intervals or seek subscribers-such deadlines and financial stresses made publishing risky and hard. Instead, he could just print issues whenever he had enough new material and then distribute them via the steamboats constantly moving across the region.

Ned launched Ned Buntline's Own in 1845. Multiple sources reference it, showing that it was small—octavo size at just seven by nine inches—but where it was published and what it contained are largely unknown because not a single issue survives (Monaghan 106; Venable 304). It is telling that in an era when prospectuses for new publications are constantly in newspapers (Ned Buntline's Magazine and the Western Literary Journal had ads in dozens of papers), not a single one appeared for Ned Buntline's Own. Further, different sources note different locations of publication-Paducah and Smithland Kentucky, Clarksville and Nashville Tennessee (Paterson 14; "Smithland"; Teitloff). This demonstrates Ned's new publishing method; he didn't seek subscribers and he didn't set up shop in any particular location. This was an itinerant paper, moving and adapting to the audiences it was serving throughout the waterways and boom cities of the expanding American West. In the Knickerbocker's April "Editor's Table" section, Clark, in his gossipy style, obliquely addressed his regular contributor's odd new publication, noting "NED BunTLINE, with 'a clear field' asks 'no favor' of his readers. He is one of your gallant, dashing sort of persons who compel admiration" (Clark, "Editor's Table" Apr. 1845: 373). 
Though no copies of Ned Buntline's Own from this era survive, some of its content does because other papers copied it for their own pages. New York's The World We Live In reprinted "Ned Buntline's New, Explanatory Modern Dictionary," a tongue-in-cheek guide that included sample definitions such as: "Education.-Teaching the young men how to shoot; buying a piece of parchment written in Latin, and tacking A.M. instead of A.S.S., to the owner's name; teaching a young lady how to talk French, walk Spanish, faint gracefully and dance the Polka" (15 Aug. 1846: 59). Scientific American also reprinted this definition of "Education" except without the risque "A.S.S." section, showing that Ned's humor was popular but a bit racy (3 Oct. 1846: 10). And in May of 1846 papers from Vermont to Ohio reprinted "The Veiled Lady; or, Who Can She Be?” by Ned Buntline (Middlebury Gazette 7 May 1845: 1; Huron Reflector 20 May 1845: 1). Most attributed it to the Knickerbocker, Ned's usual publisher, but this story never appeared in its pages-it must have come from Ned Buntline's Own. The theme of the story matches the reality of Ned's life at the time: it is about a young Spanish bride who tricks her wandering husband into falling in love with her all over again and then shaming him for neglecting her. Throughout this period Ned was constantly travelling, leaving Severina behind in Nashville where she continued to suffer from ill health. He was back in Nashville in June, however, and his friend, George Allen, was surprised to find that besides writing, Ned was also dealing with slave traders and hanging around at horse racing tracks (Larsen 115).

Given Ned's later support of abolition and his frequent condemnation of gambling, it seems odd that he had become friendly with Nashville's slave-traders and track-side gamblers, but the events that followed show what he was up to. Ned had taken a page from George Lippard, the writer he had scolded in the Literary Journal for risque writing while simultaneously praising him for his thinly-veiled exposés of corrupt officials. In 1845 Ned worked with his friends, William and George Allen who were masters of steamboats, and was conned twice in one voyage - tricked with a counterfeit $\$ 10$ bill and swindled out of a $\$ 9$ barrel of whiskey (Larsen 112). He was also aware of the ease with which people could be taken in by "confidence men"-indeed Ned himself was engaged in this behavior, for during this time he continued to promote the Literary Journal though he knew it was collapsing, collecting its three-dollar annual subscription fee for himself (Republican Banner 23 Jul. 1845: 2). This gave him an idea for his own paper-he would dress as an awe-struck farmer travelling for the first time, or as a prosperous but naïve Easterner, and thus lure-in and expose the con-artists and confidence men of the region, publishing their names and games in his paper (Halttunen 16-18; Monaghan 104). 
By that summer, after three months of Ned ignoring the Literary Journal, and with no new issue on the horizon, Ned's partners called it quits. On 22 July Lucius Hine announced that he had ended his partnership with E. Z. C. Judson and that the "Western Literary Journal and Monthly Review is this day dissolved" (Hine, Huron Reflector 22 Jul. 1845: 2). He apologized to subscribers and offered reimbursement noting: "I feel compelled to say, that this unfortunate event has not been occasioned by any fault of mine, as I believe-although the loss is all my own, and makes me poor indeed" (2). He explained: "The Journal was once in a flourishing condition, and would be so now, had that constancy, industry, energy, economy and zeal, pledged to it, been maintained" (2). Upon seeing this announcement, the journal's other partner, Hudson Kidd, feared people would think his lack of zeal had killed the journal and thus published a follow-up statement, printing a letter in which Hine praised him and emphatically placed the blame where it belonged: "The faithless conduct and reckless instability of E. Z. C. Judson, partner in the concern, caused the death of the journal" (Kidd, Republican Banner 23 Jul. 1845: 2). Kidd added: "I, also, am justified in saying [that Judson] . . . is as unprincipled, and at the same time as plausible a scoundrel, as was ever received and tolerated in good society" (2).

These statements, combined with the slanderous remarks he made about prominent Nashville residents in Ned Buntline's Orwn, made things a bit hot for Ned, so he once again packed up Severina and moved downriver to Smithland, Kentucky, renting rooms at the inexpensive Gordon House that overlooked the confluence of the Cumberland and Ohio Rivers. Smithland had a press that was happy to print his paper, and once he had new issues in hand, Ned would make the day-long steamboat trip back up the Cumberland to Nashville, selling issues at every wharf along the way (Republican Banner 16 Jun. 1845: 2; "Smithland"). This was an exciting new way to run a publication and it suited Ned's frenetic energy and love of adventure. He was constantly traveling and cavorting with scammers and scoundrels. He was also perpetually writing stories, humorous sketches, and public exposés that allowed him to adopt an air of civic-minded reform while graphically describing the salacious actions of supposedly upstanding citizens-Lippard's scandal-as-reform style. But as the summer ended, Ned decided he needed to re-connect with the Knickerbocker because his success was largely dependent on his literary reputation and it would be nice to have more pay coming in during the winter months. He sent a proposal for a series of autobiographical sketches and was thrilled by Clark's public reply in the October edition, thanking "our esteemed and gifted friend, 'NeD BuntLine," and announcing the publication of "Ned Buntline's LifeYarn”" (Clark, "Editor's Table" Oct. 1845: 382). 
Pleased with his new contract, Ned continued to travel, gathering gossip and writing stories for Ned Buntline's Own. That November, when the Knickerbocker printed the first part of his "Life-Yarn" (Buntline, "Life-Yarn, Part I" Nov. 1845: 432-42), Ned was busy making material for future chapters. At the wharf in Eddyville just up-river from Smithland, he learned that three fugitives wanted for a gruesome murder in Gallatin, Tennessee and with a $\$ 500$ reward on their heads, had fled downriver and were thought to be in the area. Arming himself, Ned set out after them. Remarkably he found and apprehended two of them, and after tying them to a tree, set off after the third who escaped after an exchange of fire. The Knickerbocker excitedly reported all of this via a correspondent who encountered Ned on his way to Gallatin with his two prisoners to collect his reward (Knickerbocker Nov. 1845: 27). Surely readers thought this was just a talltale to help promote Ned's "Life-Yarn” series—he was becoming known for his entertainingly stretched stories-but in this case, it was true. Tennessee's treasury report for 1845-46 includes an expenditure line: “E. Z. C. Judson, for apprehending fugitive, \$333.33"-two-thirds of the $\$ 500$ reward ("Conditions and Operations").

From the time Ned and Severina left Nashville amidst controversy in July, Ned was constantly on the move. He doted on his wife when he was home, but such domestic times were rare. Severina spent most of her time alone in Smithland and often lacked funds for basic expenses (Larsen 115). The income from Buntline's Own was sporadic at best, and though the Knickerbocker promised money, it often lacked funds itself and fell behind on payments. Furthermore, Ned was far from financially responsible-his Literary Journal partners had learned that the hard way. As 1845 drew to an end, Ned was still using their meager resources to print Ned Buntline's Own in Smithland, but he distributed it primarily among Nashville's 8,000 residents who were alternately thrilled and horrified by the sometimes valiant, sometimes scandalous activities he reported about their fellow residents. As both the "editor of a scurrilous paper" and a nationally-known writer, he gained regional notoriety, cheered for his daring and ability, but also scorned for his lack of propriety, for he often reveled in the same scandalous behaviors he exposed in others ("Great Excitement"). When he showed up in Nashville during the Christmas season he paraded about in a Spanish cloak and a Panama hat as the living embodiment of the "Ned Buntline" who, in the first part of his "Life-Yarn," had defied his oppressive father and sailed to the Caribbean, courting beautiful señoritas from Cuba to Florida. Not surprisingly, such swagger made him a hit among the younger members of the community, especially the women. He attended Nashville's many Christmas festivals, writing poems, speaking in Spanish, and cultivating an air of mystery dressed as a Fortune-Teller at masquerade balls (Blakey). One 
young mother of two, Mary Porterfield, was especially attentive-she noted later that she "had a partiality for literary characters" and thus found this "gentleman of high literary attainments" quite dashing (Blakey).

With January came the second part of "Ned Buntline's Life-Yarn," and in it Ned took time to again malign the sea tales of J. H. Ingraham. ${ }^{5} \mathrm{He}$ wrote: "Some foolish land-lubbers have Ingrabamatically described a seavoyage as being monotonous!" and then continued with a commentary on his own change of life circumstances. He exclaimed:

Go to! go to! Show me the dull scribbler in his musty garret; cob-webs for his rigging, dust for a sweetener to his atmosphere; dirty walls in quarto before his aching eyes, and a manuscript for which he'll scarce get enough to pay for the crackers and cheese which has fed his flickering life-lamp; and then I'll tell you if there's monotony afloat or ashore. (Buntline, "Life-Yarn, Part II" Jan. 1846: 37-38)

This passage helps explain Ned's constant movement, as well as the frustration he felt when he had to coop himself up to write, scrounging pennies for his prose. It also signals where he was headed-later he would move to Boston and usurp Ingraham as the foremost writer of sea-adventures for the popular serial-papers of the day. But this change in career was not to come easily-tragedy and scandal were its impetus, and in January of 1846 these motivators began to play out.

Ned was again travelling at the start of the year, and while he was away his friend George Allen stopped to visit Severina while his steamboat was docked in Smithland. He found her sick and desperately lonely and ended up staying with her until nearly midnight as she poured out her worries and woes. In his journal he recorded her frustration with Ned's family's "sneers at her religion and their contempt for her because she did not work," noting that she broke down amidst the telling of these tales, exclaiming: "Oh God if I had health!" (Larsen 115). She longed to return to Florida to visit her recently married sister, and he offered to get her to Baltimore where she could then head south, but she refused, saying she had no funds for such a journey. In the end, George left her with five dollars and a promise to soon return (115). Good to his word, two weeks later he stopped again, but was shocked by what he found: "I went up for Mrs. Judson \& they told me she was dead!" (116). Severina had passed away three days earlier on 22 January 1846 and, uncertain what to do with the body, the community buried her in an unmarked grave on Cemetery Hill (116).

5 Ingraham actually had been a sailor before he began writing, but his books were understandably shallow and poorly constructed-surviving copies show that in 1845 alone he wrote over twenty novellas for the popular press. 
Ned heard the news of Severina's death on his way down the Ohio River toward Smithland. George's sister wrote him that she had seen Ned and that he was devastated. George wrote in his journal: "Poor Edward-I have tried to write him a letter of consolation but I am not equal to it-I will let his bitter grief subside a little ere I do" (116). He then wrote to his brother William saying: "Poor fellow-his wife's death will unfit him for writing for a few weeks" (116). George received a letter from Ned that was almost incoherent, though noted that "some of his broken sentences are most eloquent" (116). On the first of March, Ned sent another brief note to George acknowledging that he had received his condolences, but replied: "I cannot write you now-for my heart is in my wife's grave and I cannot dig it up" (117). But apparently he was able to write, for onboard his steamboat that same day, William Allen saw a copy of a new edition of Ned Buntline's Own entirely dedicated to Ned "mourning for his wife." He thought there were "some good pieces in it" but that Ned clearly "wrote in distraction.... a passenger on board who knows him says he is dissipated now" (117). William understood that Ned's pain was as much from guilt as from the loss itself-his journal concluded: "sorry for it—he neglected her" (117).

By the second week of March, Ned returned to Nashville and soon met up again with Mary Porterfield for the two of them had something in common-grief. While Ned was mourning his wife, Mary was mourning a child — her infant daughter had passed away during the cold early months of the New Year. These shared losses made them sympathetic toward each other; whether they were also more is difficult to say, but how it was perceived is very clear. As papers later noted, "rumors of a painful delicate nature" soon reached the ears of Robert Porterfield and he "traced them to a Mr. E. Z. C. Judson, a man grown somewhat notorious of late" ("Lawlessness"). The rumors centered around an anonymous report that claimed Ned had been bragging about seducing Mary. John Porterfield—Robert's brother, a local merchant who traded up and down the Cumberland River-took this news to Robert. Infuriated, Robert grabbed a gun, and with his brother following him, went and found Ned. Leveling his pistol at Ned's chest, he accused him of seducing his wife. Ned emphatically denied this, swore that the rumors were false, and, pulling open his vest to expose his heart, "told him to fire, saying that, if he did, he would shoot an innocent man" ("Great Excitement"). At this point a crowd gathered and forced Robert to put away his pistol and go home. That evening he met with his pastor and together they confronted Mary who emphatically swore her innocence. Her sincerity convinced Robert and they reconciled (Blakey).

Then, two days later, on Friday the $13^{\text {th }}$, Reverend Isaac Paul saw Mary and Ned in the cemetery where Mary's daughter was buried; they 
were "talking intimately but not touching" (Blakey; "Review of the Report"). Following Mary back to her house he confronted her about what he had seen. She assured him the meeting had been accidental but that she had taken the opportunity to tell Ned they should no longer be in contact. When Robert arrived home she dutifully told him of the incident and he accepted her story and was pleased that the whole thing could now be put behind them. However, the next morning, Saturday 14 March, Robert's brother John showed up with a few other men and insisted that Robert had indeed been wronged and that justice must be done. Robert's temper again flared and, taking his pistol, he once again set out to find Ned with his brother trailing behind. Warned that trouble was brewing, Ned was armed when they encountered him at the edge of town. When he saw Ned, Robert immediately fired. All accounts note that Ned did not immediately fire back but instead again pled with Robert, insisting that the rumors were untrue, but Robert continued to fire and advance. After three shots had narrowly missed him, Ned, a noted marksman throughout his life, finally drew and fired one shot, hitting Robert above the right eye and shattering his skull. John Porterfield scooped up his brother and carried him to a doctor; Ned went directly to the Court House and turned himself in, declaring innocence on grounds of self-defense. ${ }^{6}$

That afternoon, as Robert Porterfield lay dying in bed, Ned appeared before Justice Josiah (J. P.) Ferris for preliminary examination and the courtroom was "soon thronged with an infuriated multitude" ("Great Excitement"). As the testimony began it quickly became apparent that Ned had acted in self-defense-all witnesses agreed that Robert had twice attacked him and that Ned had shown restraint and only fired as a last resort. But before any ruling was made, John Porterfield shoved his way into the court room and, armed with revolving pistols, opened fire on Ned. The crowd quickly parted, yelling: "Give Porterfield a chance at him!" and "let him Kill Judson!" "“Great Excitement"; "Tragedy at Nashville"). Two bystanders were struck by flying bullets as Ned fled from the Court House with John and others in pursuit-accounts vary, but somewhere between eight and twenty shots were fired at Ned as he ran across the square and into the grand City Hotel, but none brought him down. The mob followed and cornered him on the third floor. Ned

6 The series of events surrounding this shooting were covered by multiple newspapers, each with a slightly different version of the story. What follows is a composite that seems most likely. See "Awful Tragedy!"; "Drama of Saturday"; "Great Excitement"; "Lawlessness"; "Murder"; "Nashville Murder"; "Statement"; and "Tragedy at Nashville." 
tried to escape by sliding down a balcony post but lost his grip and fell to the flagstones below, severely injuring his hip in the process. City officials carried Ned's bruised and battered body back to the Court House and locked him away from the mob. But the events of the day were not yet over. That night about ten o'clock word spread that Robert Porterfield had finally succumbed to his wound. This news re-energized the crowd still milling about the Public Square and several armed men including some of Nashville's "most respectable citizens" ("Nashville Murder") pushed their way into the Court House, overpowered the jailor, and dragged Ned's broken form from his cell out into the square. A noose was hastily looped around his neck and he was hoisted up an awning post to hang. But while Ned was still kicking, the rope was cut and he fell to the ground, choking and gasping for breath. Later reports noted that "reason by this time began to resume its sway" ("Drama of Saturday"), and instead of attempting to lynch him again, Ned was "carried back to the jail and delivered into the hands of the keeper by the same party who had taken him out" ("Nashville Murder").

Papers across the country covered the "Nashville Incident" with shock and outrage. The Knickerbocker noted in its April edition: "There is great reason to fear that before the sentences which are now running from our pen shall have been placed in type, we shall have heard of the death of our frequent and always entertaining contributor, 'Ned Buntline"” ("Gossip with Readers"). But Ned was not dead, and he began defending himself as soon as he could pick up a pen. On 10 April, while still in the Nashville prison, he wrote Clark: "Your April number has just reached me; and I hasten to tell you that I am worth ten 'dead' men yet" (Buntline, Knickerbocker May 1846: 466-67). He then insisted: "As GoD is my judge, I never wronged Robert Porterfield. My enemies poisoned his ears, and foully belied me.... Gross injustice has been done me in the published descriptions of the affair." $\mathrm{He}$ insisted that the mob that attacked him "was raised by and composed of men who were my enemies on other accounts than the death of Porterfield. They were the persons I used to score in my little paper, 'Ned Buntline's Own.'” Because no copies of his paper survive, it is difficult to prove that this was indeed true, but from other evidence recorded in Nashville's many newspapers, especially in those covering the later trial of Mary Porterfield who was excommunicated from her church over this ordeal, it becomes quite apparent that Ned and Mary had never engaged in more than flirtations during the holiday season and had then sought each other's company in March over the grief they both felt-Ned mourning Severina and Mary her infant child (Blakey; "Review of the Report"). 
What also becomes apparent is that several prominent people in Nashville worked very hard to get Robert Porterfield to attack Ned for reasons that had nothing to do with Mary. Just days before the incident, Nashville newspapers reported the postponement of Robert and John Porterfield's parents' estate (Republican Banner 11 Mar. 1846: 3). This sale included two large houses, several parcels of land, eleven slaves, and dozens of shares of stock of the City Hotel and the Nashville TurnpikeRoad that in total were worth a small fortune. It is telling, then, that it was John Porterfield who kept pressuring his brother to attack Ned, and that after Robert's death he immediately worked to have his widow, Mary, expelled from their church via a trial that caused her to be publicly shamed out of town. His attorney also stripped her of the custody of her son and made John his ward. This attorney, Franklin Gorin, is exposed in the church trial as having manipulated statements to make it look like Ned and Mary had been having an affair-the "proof" that caused Robert to ultimately attack Ned (Blakey). Ned also claimed that one of the lynch mob was J. N. Armstrong - the son of the then US Consul at Liverpool and a former candidate for Governor of Tennessee-who led the mob in attacking him ("Statement"). Just a few months earlier Armstrong had announced that his prominently located dry-goods store, J. N. Armstrong \& Co., was suddenly "anxious to close their business" and liquidated itself at bargain prices; it seems some scandalous news had wrecked his business (Republican Banner 19 Nov. 1845: 3).

Taken in total, and given Ned's assertions about the true motivations of "his enemies," there is significant evidence to suggest that he was attacked and lynched not for an affair, but for the scandal and exposure caused by his provocative pen. It also seems that many in the community supported him. "One or two gentlemen" helped him escape John Porterfield in the courtroom ("Tragedy at Nashville"), the rope used to hang him "was intentionally cut" ("Nashville Murder"), the crowd's sentiment pushed against stringing him back up, and ultimately there was "no effort by Porterfield's friends to prosecute Judson" and he was allowed to peacefully leave town (Louisville Daily Courier 17 Apr.1846: 2). Nashville residents saw Ned and his writing as provocative and even scandalous, but ultimately they defended him. Indeed a few months after the incident George Allen passed through on his steamboat and reported, "Buntline's reputation is improved in Nashville-many folks are believing his account of the story" (Larsen 118).

In the months that followed, Ned briefly moved to Philadelphia and then New York where he finished up his "Life-Yarn" series for the Knickerbocker, but his literary course was already changing. By the fall of 1846 he moved to Boston, then the center of the sensational story-paper 
market, and, having learned lessons from Ingraham and Lippard, began mass producing thrilling stories at a break-neck rate- he wrote twelve novels in 1847 alone. One of them was The Volunteer; or, The Maid of Monterey that is thematically about the Mexican American War, but is also a thinly-veiled commentary on his time in Nashville. The story has as its hero, "George R. Blakey from Rural Choice, Kentucky"- the actual name and home-town of Mary Porterfield's uncle who served as her attorney and defender.' Blakey's published account of the "incident" in a Nashville paper largely exonerated them both in the court of public opinion (Blakey). And the villain of the story shares his name with John Porterfield's attorney, Franklin Gorin. In the novel "Gorin" is a cruel, virtue-less miscreant who constantly tries to destroy the lives of the hero and heroine-he is ultimately hanged in a scene very reminiscent of the way Ned was strung up in Nashville. Ned made $\$ 100$ (roughly half a working-man's yearly wage), for each of the stories he wrote that year, and thus by 1848 he began his own self-financed publishing efforts once again, moving to New York and delving into its underworld, repeating and refining the tactics he had learned in Nashville. He soon published a Lippard-like novel, The Mysteries and Miseries of New York, that implicated and angered many prominent leaders while garnering him huge sales. New York men's magazine, the Spirit of the Times noted it "excited quite a sensation," and was "read with extreme interest, as almost any one 'on town' cannot fail to recognise the principal characters who figure in it" (536).

Thus, by 1848, Ned had taken the unconventional writing and publication styles he had learned and cultivated along the riverways of the West and transplanted them into America's largest city, garnering him bigger markets. He relaunched Ned Buntline's Own which again exposed and angered prominent citizens while cultivating the favor of the much more numerous working classes. This again led to an "incident" that rocked a city—the May 1849 "Astor Place Riot" pitted New York's working-class against its elite residents and cost New York thousands of dollars in damages and twenty-five people their lives (Buckley). It also landed Ned (and only Ned) in jail for a year because he and his paper were blamed for inciting the riot. He was infamous once again, but also a nationally-known celebrity and one of the highest paid authors in the country. Edward Z. C. Judson had figured out how to become the literary rogue, Ned Buntline-a realization that began at the end of a rope in Nashville, Tennessee.

7 Note that Judson also praised Blakey in the dedication of another book that year, The Curse! A Tale of Crime and its Retribution, Founded on Facts of Real Life. 


\section{Works CiTED}

“Awful Tragedy!” Republican Banner [Nashville Tennessee] 16 Mar. 1846: 3. Print.

Blakey, George D. "A Report on the Proceedings of the First Baptist Church, in Nashville, in the case of Mrs. Mary D. Porterfield, widow of the late Robert R. Porterfield, who was killed by E. Z. C. Judson, together with her defense." Tri-Weekly Nashville Union [Tennessee] 16 and 18 Jul. 1846: 2. Print.

Bradshaw, T. M. Ned Buntline: So Much Larger than Life. Stamford, NY: CreateSpace, 2019. Print.

Buckley, Peter G. "The Case Against Ned Buntline: The 'Words, Signs, and Gestures' of Popular Authorship.” Prospects (1988): 249-72. Print.

Buntline, Ned. Knickerbocker Magazine 27 (May 1846): 466-67. Print.

---. "My Log-Book.” Knickerbocker Magazine 11 (May-Jun. 1838): 44352, 488-99. Print.

---. “Ned Buntline’s Life-Yarn, Part I.” Knickerbocker Magazine 26 (Nov. 1845): 432-44. Print.

---. “Ned Buntline’s Life-Yarn, Part II.” Knickerbocker Magazine 27 (Jan. 1846): 35-40. Print.

---. “Ned Buntline’s Life-Yarn, Part III.” Knickerbocker Magazine 27 (Jun. 1846): 537-44. Print.

---. "Ned Buntline’s Life-Yarn, Part IV.” Knickerbocker Magazine 28 (Jul. 1846): 62-68. Print.

---. "Ned Buntline's New, Explanatory Modern Dictionary." The World We Live In [New York City] 15 Aug. 1845: 59. Print.

---. The Curse! A Tale of Crime and its Retribution, Founded on the Facts of Real Life. Boston: Roberts and Garfield, 1847. Print.

---. The Mysteries and Miseries of New York. New York: Berford, 1848. Print.

---. "The Veiled Lady; or, Who Can She Be?" Middlebury Gazette [Wisconsin] 7 May 1845: 1. Print.

---. The Volunteer; or, the Maid of Monterey. Boston: F. Gleason, 1847. Print.

---. Western Literary Journal \& Monthly Review 1 (Nov. 1844): 26, 58-59, 63. Print.

---. Western Literary Journal \& Monthly Review 1 (Dec. 1844): 112-13. Print.

---. Western Literary Journal \& Monthly Review 1 (Jan. 1845): 183. Print.

"Conditions and Operations of the Treasury of Tennessee." Republican Banner [Nashville] 23 Oct. 1846: 2. Print.

Clark, Lewis Gaylord. “Editor's Table.” Knickerbocker Magazine 24 (Jul. 1844): 102. Print. 
---. "Editor’s Table." Knickerbocker Magazine 24 (Dec. 1844): 582-83. Print.

---. “Editor's Table.” Knickerbocker Magazine 25 (Apr. 1845): 373. Print.

---. "Editor's Table." Knickerbocker Magazine 26 (Oct. 1845): 382. Print.

Denning, Michael. Mechanic Accents: Dime Novels and Working-Class Culture in America. London: Verso, 1998. Print.

"Drama of Saturday." Republican Banner [Nashville Tennessee] 18 Mar. 1846: 2. Print.

“Gossip with Readers.” Knickerbocker Magazine 27 (Apr. 1846): 376-77. Print.

"Great Excitement in Nashville; Murder \& Lynch Law." Times-Picayune [New Orleans] 24 Mar. 1846: 1. Print.

Halttunen, Karen. Confidence Men E Painted Women: A Study of MiddleClass Culture in America, 1830-1970. New Haven, CT: Yale UP, 1982. Print.

Hine, Lucius. Huron Reflector [New York] 22 Jul. 1845: 2. Print.

Huron Reflector [New York] 20 May 1845: 1. Print.

Kidd, Hudson. Republican Banner [Nashville Tennessee] 23 Jul. 1845: 2. Print.

Knickerbocker Magazine 26 (Nov. 1845): 27. Print.

Larsen, Dennis M. "Ned Buntline and the Allen Family of Pittsburgh." Dime Novel Round Up (Fall 2015): 109-24. Print.

"Lawlessness: Mob in Nashville-Judson nearly Hung." (Reprinted from Cincinnati Gazette.) Public Ledger [Philadelphia]) 25 Mar. 1846: 1. Print.

Louisville Daily Courier [Kentucky] 17 Apr. 1846: 2. Print.

Monaghan, Jay. The Great Rascal: The Live E Adventures of Ned Buntline. Boston: Little, Brown \& Co., 1952. Print.

"Murder." (Reprinted from Nashville Gazette.) Louisville Daily Courier [Kentucky] 17 Mar. 1846: 3. Print.

“Nashville Murder.” Louisville Daily Courier [Kentucky] 19 Mar. 1846: 3. Print.

Paterson, Thomas V. The Extraordinary Public Proceedings of E. Z. C. Judson, Alias, Ned Buntline Against Thomas V. Paterson, for an Alledged Libel Contained in a Pamphlet Entitled "The Private Life, Public Career, and Real Character of That Odious Rascal Ned Buntline!!” New York, 1849. Archive.org. Web. 9 Aug. 2019.

Pond, Fred E. Life E Adventures of Ned Buntline. New York: Cadmus Bookshop, 1919. Print.

Republican Banner [Nashville Tennessee] 16 Jun. 1845: 2. Print.

---. 23 Jul. 1845: 2. Print.

---. 19 Nov. 1845: 3. Print. 
---. 11 Mar. 1846: 3. Print.

"Review of the Report of the Proceedings of the First Baptist Church in

Nashville in the Case of Mrs. Mary D. Porterfield by George D. Blakey,

Esq. of Kentucky." Tri-Weekly Nashville Union [Tennessee] 8 and 11

Aug. 1846: 2. Print.

Scientific American [New York City] 3 Oct. 1846: 10. Print.

"Smithland: One of Kentucky's Most Picturesque Towns." Crittenden

Press [Marion, KY] 11 Apr. 1895: 1. Print.

Spirit of the Times [New York City] Jan. 1848: 536. Print.

"Statement of Edward Z. C. Judson to the Public Press." (Reprinted from

Pittsburg Dispatch.) Clarksville Weekly Chronicle [Tennessee] 19 May 1846: 2. Print.

Streeby, Shelley. American Sensations: Class, Empire, and the Production of Popular Culture. Berkeley: U of California P, 2002. Print.

Teitloff, Faye Tramble. Images of America: Livingston County Kentucky.

Charleston, SC: Arcadia, 2009. Books.google.hr. Web. 9 Aug. 2019.

Tompkins, Jane. Sensational Designs: The Cultural Work of American

Fiction, 1790-1860. New York: Oxford UP, 1986. Print.

“Tragedy at Nashville. Disgraceful Mob-Lynch Law." (Reprinted from

Nashville Whig.) Perry County Democrat [Bloomfield Pennsylvania]

9 Apr. 1846: 3. Print.

Venable, W. H. "Early Periodical Literature of the Ohio Valley, part 3." Magazine of Western History 8.4 (Aug. 1888): 298-308. Archive.org. Web. 9 Aug. 2019.

\section{Mark Metzler Sawin is professor of history at} Eastern Mennonite University where he serves as chair of the history department and director of the Honors program. He earned an MA and $\mathrm{PhD}$ in American Studies from the University of Texas, and is the author of Raising Kane: Elisha Kent Kane E the Culture of Fame (2008). He served as a Fulbright scholar and as president of the Eastern American Studies Association, and is currently completing a project on the publications and life of Ned Buntline, a notorious political and literary writer of the American popular press during the 1840s-80s.

mark.sawin@emu.edu 